\title{
Human Myiasis
}

\section{K V Ramana*}

Department of Microbiology, Prathima Institute of Medical Sciences, Karimnagar, Andhra Pradesh, India

\section{Introduction}

Infestation of live human or other vertebrate host with fly larvae belonging to the insects of order Diptera is called as Myiasis. Infection happens to be by accidental ingestion of eggs or larvae of flies contaminated in food. Myiasis was either found to be asymptomatic or show gastrointestinal symptoms when ingested through food [1]. Human myiasis can present as cutaneous myiasis, anal myiasis, genitor-urinary myiasis, nasopharyngeal myiasis, ocular myiasis, body cavity myiasis, wound myiasis, aural myiasis and intestinal myiasis [2]. Myiasis caused by fly larvae has been classified in to three types including obligatory myiasis, facultative myiasis and accidental myiasis. Fly larvae that require living tissue to survive are responsible for obligatory myiasis, those that infest on wounded or necrosing tissue cause facultative myiasis and those fly larvae that are accidentally ingested or deposited on tissues of human or animals may be responsible for accidental myiasis. Fly larvae belonging to the families Calliphoridae (blowflies), Rhinoestrus spp. (botflies), Gasterophilus spp., Hypoderma spp., Chrysoma spp. and Sarcophagidae (flesh flies) are frequently responsible for myiasis in both pet and domestic animals and humans. Other fly larvae belonging to Anisopodidae, piophilidae, Stratiomyidae and syrphidae occasionally cause myiasis. Depending on the relationship between the host and the infesting fly larvae species, myiasis can be of specific, semi specific or accidental. Flies that need a host for larval development cause specific myiasis Dermatobia hominis (human botfly), Cordylobia anthropophagi (tumbu fly), Oestrus ovis (sheep botfly), Hypoderma bovis (cattle botflies or ox warbles), Gasterophilus spp. (horse botfly), Cochliomyia hominivorax (new world screwworm fly), Chrysomya bezziana (old world screwworm fly), Auchmeromyia senegalensis (Congo floor maggot) and Cuterebra spp. (rodent and rabbit botfly) [3]. Non-specific myiasis is caused by flies that lay eggs in decaying animal or vegetable matter which also develop larvae in open wounds or sores include Lucilia spp. (green botfly), Cochliomyia spp. (blue botfly), Phormia spp. ( black botfly), Calliphora spp.(blowfly) and Sarcophaga spp. (flesh fly or sarcophagids) [4]. Flies that do not need any host to develop, deposit eggs accidentally leading to pseudomyiasis which is caused by Musca domestica (housefly), Fannia spp. (latrine flies), Eriatalis tenax (rat-tailed maggots) and Muscina spp. [5]. More than fifty flies have been reportedly responsible for different types of myiasis in humans. Previous studies have showed that M. Stabulans, the common housefly is responsible for majority of cases of myiasis as the female fly oviposits around 150 eggs on the food or other decaying matter which later undergo developmental changes involving three larval stages (Figure 1) before transforming in to pupa $[6,7]$. In most of the cases, the appearance of fly larvae just indicates the consumption of food contaminated with larvae and not considered as infection. This is true because $90 \%$ of fly larvae infestation is accidental and fly larvae cannot survive and rarely produce complications [8]. Few parasitic diepterous flies only have the ability to grow on dead, necrosing or living tissues [9]. Though gastrointestinal myiasis is common, other sites from which fly larvae are reported include skin, nasopharynx, eye ear, wounds and genitourinary tract [10-18]. Incidence of myiasis was found to be related to seasonal variations where majority of the reports have been during the end of the summer through rainy season when flies breed and are found in large numbers [19]. Myiasis is a cause of concern not only in the community but also a threat in hospitals of developing and low socioeconomic countries [20]. Reports of myiasis in intensive care units of hospitals are available [21]. A probable transfer of fly larvae from mother to child was also reported in literature. Basically myiasis is the infestation of maggots the immature developmental stage of diepterous flies. Studies have observed myiasis both in animals and human [6]. Poor hygiene and low socioeconomic conditions which are normally found in rural population can be predisposed to this condition [19]. Previous reports have suggested that children may be prone to myiasis more frequently considering their playing habitats and hygiene [22]. Fly larval infestation is most often self-limiting and not result in any serious complications, which is a major cause of underreporting of human myiasis throughout the world. Diagnosis of human myiasis is usually missed by physicians due to lack of suspicion and have little idea of the specific clinical features.

\section{Epidemiology}

Human myiasis is most common in tropical regions, though reports of fly larval infestation are available throughout the world [4,19,23] Travelling to larval endemic areas may be a predisposing factor. Fly larvae show parasitism during their $1^{\text {st }}$ to $3^{\text {rd }}$ instar stages which later leave the host to continue their life cycle as pupa and then in to adult flies. Climate conditions including humidity and warm environment help larval developmental stages. Studies have showed that myiasis

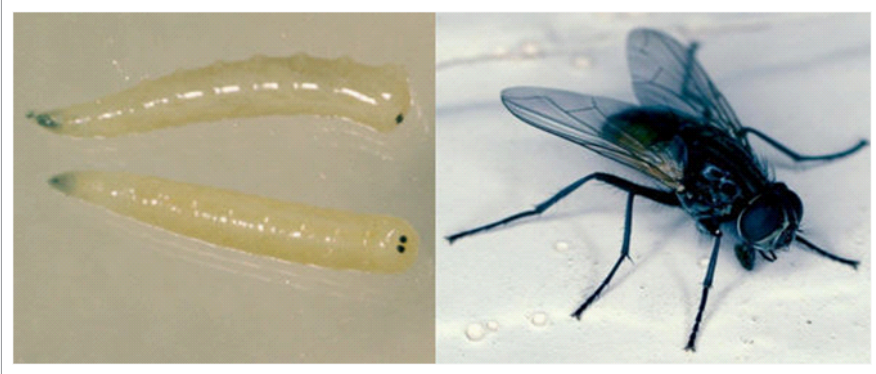

Figure 1: Larval and the adult forms of Musca domestica (housefly).

${ }^{*}$ Corresponding author: K V Ramana, Department of Microbiology, Prathima Institute of Medical Sciences, Karimnagar, Andhra Pradesh, India, Tel: 08728222779; E-mail: ramana_20021@rediffmail.com

Received March 27, 2012; Accepted March 28, 2012; Published April 01, 2012

Citation: Ramana KV (2012) Human Myiasis. J Medical Microbiol Diagnosis 1:e105. doi:10.4172/2161-0703.1000e105

Copyright: (c) 2012 Ramana KV. This is an open-access article distributed under the terms of the Creative Commons Attribution License, which permits unrestricted use, distribution, and reproduction in any medium, provided the original author and source are credited. 
may be due to fly larvae that are endemically present in a particular region or can be imported from other regions mainly by travelling $[23,24]$. Most of the fly larvae are transmitted to humans through pet or domestic animals that are infested by larvae. Veterinarians therefore should be vigilant and take necessary precautions to disinfest animals that are transported through continents. Emphasis has been shifted to molecular methods for studies on biology, epidemiology, phylogenetic and taxonomy (identification) of fly larvae that can produce significant economic loses $[25,26]$. Fly larvae comprise both medical and veterinary importance as a legal evidence in forensic entomology and is responsible as a vector for transmission of livestock parasites/pathogens. Human myiasis is rare in developed countries and may be frequently seen in tropical and sub tropical regions. Geriartric age group, poor hygiene, low socioeconomic conditions, underlying metabolic disorders such as diabetes, vascular disease reducing blood circulation and cancerous conditions can predispose to human myiasis $[27,28]$. Studies have shown that larvae adapt themselves to a particular environment and undergo hypobiosis either inside or outside the host, according to climatic environmental condition and season. Reports of infestation of a certain type of fly larvae among domestic animals in southern Europe and use of specific antiparasitic treatment could well explain the degree of parasitic biodiversity and the level of species selection in fly larvae [7]. Heavy rain falls may predispose livestock to be infested with fly larvae that may in turn lead to infestation in other inhabitants including humans. Forest dwelling either due to professional cause or otherwise can predispose to fly larval infestation. Human myiasis is directly related to the endemicity of the fly larval species prevalent in that area [23].

\section{Clinical Features}

Human myiasis clinical features vary according to the site of infestation and the type and number of fly larvae. Asymptomatic infestation cannot be ruled out. Obligate myiasis causing flies create nasopharyngeal cavities (nasal bots), digestive tract bots and even involve any internal organs of animals and human [29]. Larvae can be deposited in the eye causing painful ophthalmomyiasis resembling a foreign body in the eye sensation. Inflammatory reaction at the site if larviposition due to mast cell activation and IgE production may limit larval development [30]. Larvae accidentally ingested in mouth can be present in oral cavity in the damaged gums and teeth spaces. Larval infestation of skin, cutanious myiasis can present in different forms like furuncular myiasis, creeping myiasis, wound myiasis and subcutaneous myiasis. Cutaneous myiasis or larva migrans (normally observed in Ancylostoma duodenale a nematode) can be seen on feet, buttocks and trunk and presents as a boil, pruritic or erythematous, pain full masses or lines formed due to movement of larvae in skin and sub cutaneous tissues [31]. Larval presence in the ear (aural myiasis), can lead to perforation of tympanic membrane, hearing loss and hemorrhage and rarely the larvae may migrate in to meninges. Gastrointestinal myiasis, caused due to accidental ingestion of fly larvae may be presenting as nausea, vomiting, abdominal pain, abdominal distention, loss of appetite, weight loss and episodic diarrhea similar to intestinal parasites. Larvae from gastrointestinal tract may move in to skin and other organs. Gastrointestinal myiasis is most often ignored as pseudo myiasis as most fly larvae die before reaching small intestines due to acidity. Myiasis cases involving various other organs, with different underlying conditions are reported in literature. Reports of infection in neonates reveal no predilection to age. Nosocomial myiasis though rare has been reported [32,33].

\section{Laboratory Identification}

Though majority of fly larval infestation are benign, identification assumes importance for initiating treatment where ever necessary and for epidemiological purposes [1]. Depending on the site of infestation larvae can be mechanically extracted from skin and subcutaneous skin with forceps or use pressure after applying of petrolatum, palm oil, cholesterol free oil (laser oil), wax, pork fat and paraffin to reduce oxygen supply to larvae so that it comes out for want of air other surgical procedures. Application of chemicals like ethyl chloride sprays, liquid nitrogen, $15 \%$ chloroform in oil or $1 \%$ ivermectin cream have been used alone or in combination. Additionally, lidocaine can be injected into the base of the tissue cavity which the larva inhabits, thereby forcing the larva to the surface through hydrostatic pressure. Extraction of larvae by pressure application is not preferred as it may lead to larval lysis that may in turn lead to severe hypersensitive reactions. Stool examination in case of gastrointestinal manifestation is preferred [26]. Fly larval stages are identified macroscopically based on shape, size, and color. Presence of segments, dorsal and ventral surfaces, anterior and posterior spiracles and presence of spines on body can aid in identification. Light microscopy and electro micrographic studies can confirm the identification and stage of larvae based on the presence of papillae, arrangement of anterior and posterior spiracles. Culture of larval forms to their adult forms is another method in identification [34,35].

\section{Conclusion}

Fly larvae (Lucilla sericata) have been reportedly used in debridement of necrosed tissue, called as maggot debridement technique (MDT) [36]. In spite of rapid advances in the medical field we have many areas to focus, that can be seen as a public health concern. Human myiasis though not a serious problem now, should we be complacent may be turning out in to a huge burden in due course of time. Sporadic reports, inadequate literature of fly larval infestations in human have underestimated the seriousness of the probable threat [37]. Fly larval infestation can cause significant loss to livestock at large and human infestation can be responsible for huge economic loss [38]. Reports of carriage of various pathogenic viruses, parasites and bacteria by fly larvae should be a cause of concern. Not much space is devoted in parasitological and a microbiology text book to describe human myiasis is another limiting factor. Physicians, veterinarians, entomologists, parasitologists and microbiologists should be involved in proper diagnosis of fly larval infestation based on clear guide to suspicion and treatment initiated where and when necessary to reduce the morbidity [39]. Control measures include trapping flies using trap and bait technique, vaccination of animals and chemical treatment to reduce fly infestation $[40,41]$.

\section{References}

1. John, david and Petri, William (2006) Markell and Voge's Medical Parasitology: 9th Edition. Missouri: Saunders Elsevier P: 328-334.

2. Palmer ED (1970) Entomology of the gastrointestinal tract: a brief review. Mil Med 135: 165-176.

3. Angulo-Valadez CE, Scholl PJ, Cepeda-Palacios R, Jacquiet $P$, Dorchies $P$ (2010) Nasal bots...a fascinating world! Vet Parasitol 174: 19-25.

4. Fernandes LF, Pimenta FC, Fernandes FF (2009) First report of human 
myiasis in GoiáS state, Brazil: frequency of different types of myiasis, their various etiological agents, and associated factors. J Parasitol 95: 32-38.

5. Dogra SS, Mahajan VK (2009) Oral myiasis caused by Musca domestica larvae in a child. Int J Pediatr Otorhinolaryngol 73: 1604-1605.

6. Hall M, Wall R (1995) Myiasis of humans and domestic animals. Adv Parasitol 35: $257-334$

7. Otranto D, Colwell DD (2008) Biodiversity and extinction versus control of oestrid causing myiasis in Mediterranean area. Parasite 15: 257-260.

8. Touré SM (1994) Myiases of economic importance. Rev Sci Tech 13: 10531073.

9. Whitehorn JS, Whitehorn C, Thakrar NA, Hall MJ, Godfrey-Faussett P, et al (2010) The dangers of an adventurous partner: Cordylobia anthropophaga infestation in London. Trans R Soc Trop Med Hyg 104: 374-375.

10. Avula JK, Avula H, Arora N, Manchukonda UK, Vivekavardhan Reddy N (2011) Orofacial myiasis of the gingiva and nasal cavity: a report of two cases and general review. J Periodontol 82: 1383-1388.

11. Perez-Eid C, Mouffok N (1999) Human urinary myiasis caused by Fannia canicularis (Diptera, Muscidae) larvae in Algeria. Presse Med 28: 580-581.

12. Shaunik A (2006) Pelvic organ myiasis. Obstet Gynecol 107: 501-503.

13. Komori K, Hara K, Smith KG, Oda T, Karamine D (1978) A case of lung myiasis caused by larvae of Megaselia spiracularis Schmitz (Diptera: Phoridae). Trans R Soc Trop Med Hyg 72: 467-470.

14. Yuichi C, Satoshi S, Masatomo $H$, et al. (2005) Vaginal myiasis due to Sarcophaga peregrina (Diptera: Sarcophagidae) on a patient with atrial fibrillation, cerebral infarction and leg amputation [abstract]. Med Entomol Zool 56: 247-49.

15. Mumcuoglu I, Akarsu GA, Balaban N, Keles I (2005) Eristalis tenax as a cause of urinary myiasis. Scand J Infect Dis 37: 942-943

16. Ogbalu OK, Achufusi TG, Adibe C (2006) Incidence of multiple myiases in breasts of rural women and oral infection in infants from the human warble fly larvae in the humid Tropic-Niger Delta. Int J Dermatol 45: 1069-1070.

17. Caumes E, Carrière J, Guermonprez G, Bricaire F, Danis M, et al. (1995) Dermatoses associated with travel to tropical countries: a prospective study of the diagnosis and management of 269 patients presenting to a tropical disease unit. Clin Infect Dis 20: 542-548.

18. Rossi MA, Zucoloto S (1973) Fatal cerebral myiasis caused by the tropical warble fly, Dermatobia hominis. Am J Trop Med Hyg 22: 267-269.

19. Delenasaw Y, Worku L, Solomon GS, Helmut K (2007) Human myiasis in an endemic area of Southwestern Ethiopia: Prevalence, knowledge, perceptions and practices. Ethiop J Health Dev 21: 166-172.

20. Ghosh T, Nayek K, Ghosh N, Ghosh MK (2011) Umbilical myiasis in newborn. Indian Pediatr 48: 321-323.

21. Mielke U (1997) Nosocomial myiasis. J Hosp Infect 37: 1-5

22. Dehecq E, Nzungu PN, Cailliez JC, Guevart E, Delhaes L, et al. (2005) Cordylobia anthropophaga (Diptera: Calliphoridae) outside Africa: a case of furuncular myiasis in a child returning from Congo. J Med Entomol 42: 187-192.

23. Derraik JG, Heath AC, Rademaker M (2010) Human myiasis in New Zealand: imported and indigenously-acquired cases: the species of concern and clinical aspects. N Z Med J 123: 21-38.

24. Dalton SC, Chambers ST (2009) Cutaneous myiasis due to Dermatobia hominis (the human botfly) in a New Zealand traveller returned from South America. N Z Med J 122: 95-99.

25. Otranto D, Stevens JR (2002) Molecular approaches to the study of myiasiscausing larvae. Int J Parasitol 32: 1345-1360.

26. John Smart, Karl Jordan, RJ Whittick, British Museum (Natural History) - 1943 - 269 pages $A$ handbook for the identification of insects of medical importance 2007, the university of Michigan, Printed by order of the Trustees of the British Museum, 1943.
27. Sesterhenn AM, Pfützner W, Braulke DM, Wiegand S, Werner JA, et al. (2009) Cutaneous manifestation of myiasis in malignant wounds of the head and neck. Eur J Dermatol 19: 64-68.

28. Ogugua KO, Achufusi TG, Eme EO, Dorcas SB, Chika HA (2011) Human Myiasis in Neonates and Children of the Niger Delta Wetlands and South-East Nigeria. Journal of Cosmetics, Dermatological Sciences and Applications 1 : 171-176.

29. Ito E, Honda A, Honjo M, et al. (2003) Migratory myiasis due to Hypoderma bovis [abstract, original in Japanese]. Rinsho Derma 45: 129-131.

30. Batista-da-Silva JA, Moya-Borja GE, Queiroz MM (2011) Factors of susceptibility of human myiasis caused by the New World screw-worm, Cochliomyia hominivorax in São Gonçalo, Rio de Janeiro, Brazil. J Insect Sci 11: 14.

31. Clyti E, Deligny C, Nacher M, Del Giudice P, Sainte-Marie D, et al. (2008) An urban epidemic of human myiasis caused by Dermatobia hominis in French Guiana. Am J Trop Med Hyg 79: 797-798.

32. Cepeda-Palacios R, Scholl PJ (2000) Factors affecting the larvipositiona activity of Oestrus ovis gravid females (Diptera: oestridae). Vet Parasitol 91 93-105.

33. Freedman DO, Weld LH, Kozarsky PE, Fisk T, Robins R, et al. (2006) Spectrum of disease and relation to place of exposure among ill returned travelers. N Eng J Med 354: 119-130.

34. Ahmad AK, Abdel-Hafeez EH, Makhloof M, Abdel-Raheem EM (2011) Gastrointestinal myiasis by larvae of Sarcophaga sp. and Oestrus sp. in Egypt: report of cases, and endoscopical and morphological studies. Korean J Parasitol 49: 51-57.

35. de Azeredo-Espin AM, Lessinger AC (2006) Genetic approaches for studying myiasis-causing flies: molecular markers and mitochondrial genomics. Genetica 126: 111-131.

36. Sherman RA, Hall MJ, Thomas S (2000) Medicinal maggots: an ancient remedy for some contemporary afflictions. Annu Rev Entomol 45: 55-81.

37. Otranto D (2001) The immunology of myiasis: parasite survival and hos defense strategies. Trends Parasitol 17: 176-182.

38. Osorio J, Moncada L, Molano A, Valderrama S, Gualtero S, et al. (2006) Role of ivermectin in the treatment of severe orbital myiasis due to Cochliomyia hominivorax. Clin Infect Dis 43: e57-59.

39. Gealh WC, Ferreira GM, Farah GJ, Teodoro U, Camarini ET (2009) Treatment of oral myiasis caused by Cochliomyia hominivorax: two cases treated with ivermectin. Br J Oral Maxillofac Surg 47: 23-26.

40. Hall MJ (1995) Trapping the flies that cause myiasis: their responses to hoststimuli. Ann Trop Med Parasitol 89: 333-357.

41. East IJ, Eisemann $\mathrm{CH}$ (1993) Vaccination against Lucilia cuprina: the causative agent of sheep blowfly strike. Immunol Cell Biol 71: 453-462. 